\title{
МЕЖДУНАРОДНО-УГОЛОВНОЕ ПРАВО КАК ПОДОТРАСЛЬ РОССИЙСКОГО УГОЛОВНОГО ПРАВА: СОВРЕМЕННОЕ СОСТОЯНИЕ И ПРОБЛЕМЫ
}

Аннотация. Статья посвящена текущеему положению дел в связи с положениями, происходящими из международного уголовного права, в российском уголовном праве. Основываясь на этом, он приходит к выводу, что существует особая подотрасль российского уголовного права, которая может быть названа «международно-уголовное право». Эта подотрасль охватывает группу преступления в Особенной части уголовного кодекса и изменяет общие нормы уголовного права. В предмет исследования также входят нормы уголовного законодательства зарубежных государств. Автор исследует историю соответствующих положений в национальном уголовном законодательстве, раскрывает их отличительные особенности и проводит сравнение с зарубежным опытом в этих вопросах. Очерчиваются текущие проблемы соотносительно с этими преступлениями и общими нормами. Особое внимание уделяется перспективам будущих имплементационных процедур и научным разработкам в этой области. Автор заключает, что наличие современного по своему уровню уголовного законодательства и сильной уголовно-правовой теории представляют собой задачу ближайшего будущего в российской уголовно-правовой доктрине.

Ключевые слова: Международное уголовное право, уголовный кодекс, преступления против человечности, геноцид, военные преступления, имплементация, источники уголовного права, обратная сила, международное право, международный уголовный суд. Abstract: The article focuses on the current status of international criminal law provisions in Russian criminal law. The author outlines the history of these provisions within the national criminal legislation, reveals their specific features, and makes a comparison with the foreign experience on this matter. Based on the aforementioned, he concludes that there is a specific sub-branch within Russian criminal law, which can be referred to as 'internationally originated criminal law.' This sub-branch encompasses the group of crimes in the special part of the criminal code and modifies the general rules of criminal law. Furthermore, the current problems with regards to these crimes and general rules are outlined. Special attention is given to the future prospects of implementation procedures and doctrinal research in this area. The author concludes that to have an up-to-date criminal legislation and a strong criminal legal theory, is a task for the future development within Russian criminal legal doctrine.

Keywords: Sources of criminal law, implementation, war crimes, genocide, crimes against humanity, criminal code, international criminal law, retroactive force, international law, international criminal court. 
DOI: $10.7256 / 2226-6305.2015 .3 .15751$

При цитировании этой статьи сноска на dоі обязательна

Международное право и международные организации•з•2015 International Law and International Organizations

\section{I. Введение в международно-уголовное право: подотрасль и история ${ }^{1}$.}

Последние чуть более чем два десятилетия показывают беспристрастному наблюдателю быстрый рост международного уголовного права. Трагические события в Камбодже, Руанде, Сьерра-Леоне, Югославии оживили корпус норм, который, казалось бы, должен был прийти в забвение после окончания судебных процессов по результатам Второй мировой войны. Закономерным итогом этого стало создание Международного уголовного суда, деятельность которого с 2002 г. нацелена на то, чтобы «положить конец безнаказанности лиц, совершающих такие преступления, и тем самым способствовать предупреждению подобных преступлений» (преамбула к Римскому статуту Международного уголовного суда от 17 июля 1998 г.). Вместе с тем, будучи по своему источнику международно-правовым явлением, международное уголовное право, следуя западно-правовой традиции «права на виселицу» в качестве одной из зримых составляющих суверенитета ${ }^{2}$, исходит из

${ }^{1}$ Поводом к написанию данной статьи стала дискус-
сия, имевшая место 29 мая 2015 г. на Петербургком
международном юридическом форуме (круглый стол
«Международная и национальная уголовная юстиция.
Совместимость и взаимодействие»), в ходе которой
представителями в основном науки международного
права были высказаны суждения о вполне благополуч-
ном состоянии дел в этой области в России.
Статья написана в рамках научного проекта (№ $15-$
$01-0015)$, выполненного при поддержке Программы
«Научный фонд НиУ ВШЭ» в $2015-2016$ гг. Работа
выполнена при финансовой поддержке Правительства
РФ в рамках реализации «Дорожной карты» Программы
$5 / 100$ Национального исследовательского университета
«Высшая школа экономики». При подготовке статьи
использована СПС «КонсультантПлюс».
${ }^{2}$ «Как барон, вы в Англии имеете право на виселицу
о четырёх столбах, и в Сицилии, как маркиз, - на
виселицу о семи столбах; у простого дворянина ви- принципа комплементарности ${ }^{3}$. Согласно ему, Международный уголовный суд (arguendo на будущее ответственный за все случаи преследования по международному уголовному праву на международном уровне) «дополняет национальные системы уголовного правосудия» (ст. 1 Римского статута) ${ }^{4}$.

Таким образом, приоритет в расследовании, преследовании и наказании деяний, образующих преступления согласно международному уголовному праву, принадлежит отдельным странам, и лишь при их неспособности или нежелании сделать это вмешаться может и должно международное сообщество 5 .

селица о двух столбах, у ленного владельца - о трёх, а у герцога - о восьми» (Виктор Гюго. «Человек, который смеётся»).

${ }^{3} \mathrm{C}$ учётом ограниченности во времени юрисдикции Нюрнбергского трибунала, трибуналов по бывшей Югославии и Руанде и особых исторических условий их создания, их исключительная или преимущественная юрисдикция - это, скорее, исключение из правила. Постоянно действующий Международный уголовный суд основан на предположении «о том, что непосредственное применение международного уголовного права международными судами и далее будет исключением, а не правилом...» (см.: Верле Г. Принципы международного уголовного права / пер. с англ. С. В. Саяпина. Одесса; M., 2011. C. 112).

${ }^{4}$ В своём особом мнении по делу судья Анита Ушацка охарактеризовала принцип комплементарности как базовый в деятельности Международного уголовного суда, позволяющий достичь баланса между суверенитетом и эффективно работающим Судом и позволивший сам по себе достичь соглашения по вопросу принятия Римского статута в 1998 г. (см.: Appeals Chamber, Prosecutor v Saif Al-Islam Gaddafi and Abdullah Al-Senussi, "Judgement on the appeal of Lybia against the decision of Pre-Trial Chamber I of 31 May 2013 entitled 'Decision on the admissibility of the case against Saif Al-Islam Gaddafi'”, Dissenting Opinion of Judge Anita Ušacka, 21 May 2014, ICC-01/11-01/11 (OA), para 14-18).

5 В этом отношении показательны положения ст. 17 и сл. Римского статута, основывающиеся на конструкции нежелания или неспособности государства «вести расследование или возбудить уголовное преследование должным образом» как условия приемлемости дела Международным уголовным судом. 
И здесь в последние десятилетия наблюдается явный, значимый и интересный для исследования процесс, удачно поименованный судьёй Международного уголовного суда в отставке Анитой Ушацкой как domestication of international criminal law, или «одомашнивание» международного уголовного права ${ }^{6}$. Его реальность, как можно заключить, обусловлена необходимостью имплементации норм международного уголовного права в национальное законодательство отдельно взятых государств.

Не осталась в стороне от этого процесса и Российская Федерация, причём самые первые шаги в этом отношении в нашем уголовном законодательстве были предприняты ещё задолго до современного всплеска интереса к международному уголовному праву.

Так, в дооктябрьском законодательстве соответствующие преступления в основном связывались с военно-уголовным правом. Статья 267 Воинского устава о наказаниях (1868 г.) предусматривала ответственность за самовольное наложение контрибуции деньгами или припасами на жителей мест, занятых войсками, или за самовольное увеличение таких сборов, наложенных надле-

К слову, неспособность связывается в том числе с отсутствием возможности «осуществлять судебное разбирательство ещё по каким-либо причинам» (п. 3 ст. 17 Римского статута), к которым в литературе относится в том числе отсутствие применимого национального уголовного законодательства (см., например: Верле Г. Указ. соч. C. 160-161, 164; Helmut Satzger, International and European Criminal Law (CH Beck 2012), p. 279).

6 Этот термин был ею использован в выступлении 29 мая 2015 г. на Петербургском международном юридическом форуме (круглый стол «Международная и национальная уголовная юстиция. Совместимость и взаимодействие»). Другие авторы пишут о конвергенции международного и национальных правопорядков в этой области (см.: Matthias Goldmann, 'Implementing the Rome Statute in Europe: From Sovereign Distinction to Convergence in International Criminal Law?' (2005) 16 Finnish Yearbook of International Law 5, 7-9). жащим порядком; ст. 273-274-за обобрание раненых или убитых солдат неприятеля; ст. 275 - за мародёрство (т.е. захват у жителей областей, армией занимаемых, припасов, одежды и других вещей, а равно всякий не определённый законом побор с обывателей). В 1911 г. в Воинском уставе о наказаниях устанавливается уголовная ответственность за самовольное ношение повязки Красного Креста (ст. 258 $)$, самовольное поднятие флага Красного Креста (ст. 258²), дурное обращение с больными и ранеными (ст. 2583). Наряду с этим была усилена ответственность за преступные действия, ранее предусмотренные ст. 273-275 устава: обновлённая ст. 279 устава предусмотрела за разбой, грабёж, умышленное зажигательство или потопление чужого имущества в военное время наказание в виде смертной казни. Комментарий на эту норму указывает, что с отменой ст. 273-275 устава ранее предусматривавшиеся ими преступные действия должны теперь квалифицироваться по ст. $279^{7}$.

В советский период развитие уголовного законодательства в этой области было незначительным, если не считать периода Великой Отечественной войны. Так, ст. 214 УК РСФСР 1922 г. устанавливала уголовную ответственность за мародёрство, т.е. «противозаконное отобрание при боевой обстановке у гражданского населения принадлежащего последнему имущества, с употреблением угрозы военным оружием и под предлогом необходимости сего отобрания для военных целей, а также снятие с корыстной целью с убитых и раненых находящихся у них вещей»; санкция за это преступление приравнивалась к бандитизму, что могло влечь

\footnotetext{
${ }^{7}$ См.: Воинский устав о наказаниях. 6-е изд. / сост. В. Ф. Огнев, испр. и доп. А. С. Лыкошин. Пг., 1916. C. 330 .
} 
применение смертной казни. Статья 18 более позднего Положения о воинских преступлениях (утверждённого ЦИК СССР 31 октября 1924 г.) устанавливала уголовную ответственность за «противозаконное насилие над гражданским населением, учинённое военнослужащим в военное время или при боевой обстановке» (с санкцией при отягчающих обстоятельствах вплоть до смертной казни); ст. 17 Положения фактически повторяла ст. 214 УК РСФСР 1992 г. В свою очередь, ст. $193^{17}$ и $193^{18}$ УК РСФСР 1926 г. воспроизводили ст. 17 и 18 Положения 1924 г. Обновлённое Положение о воинских преступлениях (утверждено ЦИК СССР, СНК СССР 27 июля 1927 г.) расширило круг уголовно наказуемых деяний за счёт криминализации дурного обращения с пленными (ст. 29), ношения в районе военных действий знаков Красного Креста или Красного Полумесяца лицами, не имеющими на то права, отдачи начальником распоряжения о ношении их упомянутыми лицами (ст. 30) и злоупотребления в военное время флагами или знаками Красного Креста и Красного Полумесяца или окраской, присвоенной транспортным средствам санитарной эвакуации (ст. 31). Ответственность за ранее единое мародёрство была дифференцирована в ст. 27 (мародёрство в отношении убитых и раненых) и 28 (разбой, грабеж, противозаконное уничтожение имущества и насилие, а равно противозаконное отобрание имущества под предлогом военной необходимости, совершаемые по отношению к населению в районе военных действий). Эти четыре состава впоследствии без существенных изменений были воспроизведены в ст. 30-33 Закона СССР от 25 декабря 1958 г. «Об уголовной ответственности за воинские преступления».

Во время Великой Отечественной войны был принят законодательный акт, который в первый и единственный раз криминализировал в российском уголовном праве прообраз преступлений против человечности. Указ Президиума Верховного Совета СССР от 19 апреля 1943 г. № 39 «О мерах наказания для немецко-фашистских злодеев, виновных в убийствах и истязаниях советского гражданского населения и пленных красноармейцев, для шпионов, изменников родины из числа советских граждан и для их пособников» предусмотрел уголовную ответственность в виде публичной смертной казни через повешение: «...немецкие, итальянские, румынские, венгерские, финские фашистские злодеи, уличённые в совершении убийств и истязаний гражданского населения и пленных красноармейцев, а также шпионы и изменники родины из числа советских граждан караются смертной казнью через повешение» (ст. 1; ст. 2 указа устанавливала, что «пособники из местного населения, уличённые в оказании содействия злодеям в совершении расправ и насилий над гражданским населением и пленными красноармейцами, караются ссылкой в каторжные работы на срок от 15 до 20 лет»). Несмотря на эмоциональную окрашенность указа, в нём прослеживается определение субъектного состава лиц, подлежащих уголовной ответственности, и перечень наказуемых деяний, в который кроме шпионажа и измены Родине включены убийства и истязания гражданского населения и пленных красноармейцев. Юридико-технически эти действия ближе к военным преступлениям, однако судебная практика применения указа рассматривает его достаточно интересно: считается, что действия, подпадающие под ст. 1 указа, одновременно охватываются и п. «с» $\S 1$ ст. 2 Закона № 10 Контрольного Совета в Германии от 20 декабря 1945 г. «О наказании лиц, виновных в военных преступлениях, преступлениях против мира и против чело- 
вечности» ${ }^{8}$, образуя преступления против человечности. Соответственно, если деяние совершалось на территории Союза ССР, временно оккупированной странами Оси, то применению подлежал указ 1943 г;; если же на территории иных государств - то Закон № $10^{9}$. Таким образом, убийства и истязания гражданского населения могли иметь место на оккупированных территориях или в связи с военными действиями, образуя военное преступление, или как следствие преступной политики стран Оси, образуя преступления против человечности.

УК РСФСР 1960 г. расширил круг уголовно наказуемых деяний за счёт криминализации пропаганды войны (ст. 71) и сохранил в ст. 266-269 ту же схему ответственности за воинские преступления, что и закон 1958 г.

Возвращаясь к теории уголовного права, можно говорить о формировании подотрасли уголовного права. Её наименованием могло бы стать «международно-уголовное право» ${ }^{10}$. Подотрасли уголовного права, сохраняю-

\footnotetext{
${ }^{8}$ Предусматривает в соответствующей части ответственность за преступления против человечности, т.е. «зверства и правонарушения, включая, но не ограничиваясь убийствами, похищениями, отправлением в рабство, в тюрьму, депортацией, пытками, изнасилованиями и остальными бесчеловечными действиями по отношению к мирному населению, преследования на политической, расовой или религиозной основе с нарушением и без нарушения законодательства страны, на территории которой это происходит».

${ }_{9}^{9}$ Определения Военной коллегии Верховного Суда РФ от 9 декабря 2004 г. № 4н-00307, от 20 июня 2006 г. № $3 \mathrm{H}-00143 / 06$.

${ }^{10}$ Предлагаемое наименование, на наш взгляд, самое удачное. Во-первых, оно не дублирует общемировое «международное уголовное право». Во-вторых, оно следует традициям наименования подотраслей в России через описание их специфики и указанием на «уголовность» (военно-уголовное право и т.п.). В-третьих, возможные лингвистические конструкции с использованием заглавия главы 34 УК РФ слишком тяжеловесны, что, вместе с тем, не означает приемлемости такого заглавия в уголовном законе самого по себе.
}

щие видимое единство с остовом уголовного права, вместе с тем обладают особыми отличительными признаками, не являясь лишь структурным элементом отрасли, т.е. «ступенькой» на пути от последней к институтам $^{11}$. Во-первых, они связаны с уголовной ответственностью в особой сфере охраняемых уголовным законом отношений или в связи с совершением преступлений особой категорией субъектов. Во-вторых и что более важно, подотрасли уголовного права, кроме наличия обособленной группы деяний в Особенной части УК РФ, присуще развитие сравнительно автономных от «общеуголовных» своих, особых норм и институтов в Общей части, уточняющих или замещающих пер-

11 Указывают на автономию норм уголовного права, созданных как следствие международной унификации, ввиду закрепления таких норм в различных источниках и особых правил систематического толкования Ю. В. Трунцевский и А. А. Цветков. Они предлагают именовать этот блок «рецепированное уголовное право» и понимают под ним правовой институт («система принципов и норм международного права, инкорпорированных в российское уголовное законодательство, являющихся наряду с нормами уголовного процесса частью комплексной отрасли российского права - международного сотрудничества в борьбе с преступностью, закрепляющая: принципы экстерриториального действия уголовного закона; основания оказания правовой помощи или отказа от её предоставления запрашивающим государствам по выдаче; признаки транснациональных преступлений и основания освобождения от уголовной ответственности за их совершение; основы толкования в системе российского уголовного права норм международного права») (см.: Трунцевский Ю. В., Цветков А. А. Способы инкорпорации международно-правовых норм в российской уголовно-правовой системе // КонсультантПлюс, ๆ 134, 138-139 (Международное публичное и частное право. 2005. № 2).

Фактически в их понимании в этот блок входят все преступления, так или иначе имеющие международно-правовую связь (происхождение). Во-первых, это лишает «рецепированное уголовное право» чётких контуров; во-вторых, фактически сводит его специфику к проблеме базового источника уголовно-правовой нормы без какой-либо особой содержательной составляющей. 
вые. В-третьих, подотрасль уголовного права получает как таковая определённое научное признание, выражающееся в существовании обозначившегося круга обсуждаемых вопросов и обособленного корпуса литературы. При этом не следует делить всё уголовное право на подотрасли, равно как вряд ли приемлемо далее системно дробить подотрасли на институты; подотрасли представляют сравнительно автономные образования, связанные не столько с законодательным материалом (раздел = подотрасль и т.п.), сколько с обособлением части норм Общей части и составов Особенной части в связи с совершением определённого круга преступлений или в связи с особым статусом субъекта.

Соответственно, международно-уголовное право удовлетворяет всем приведённым критериям, а потому (наряду с военно-уголовным правом и экономическим уголовным правом ${ }^{12}$ ) должно быть признано полноценной подотраслью уголовного права.

\section{ІІ. Сравнительно-правовые наблюдения.}

Выделение самостоятельного блока о преступлениях, входящих в корпус международного уголовного права, можно проследить и в зарубежном праве. Приведём только несколько примеров, хотя количество стран, изменивших своё уголовное законодательство под влиянием современного развития международного уголовного права, измеряется уже десятками ${ }^{13}$.

\footnotetext{
${ }^{12}$ См.: Есаков Г. А. Экономическое уголовное право: понятие, содержание и перспективы // Lex Russica (Научные труды Московского государственного юридического университета имени О. Е. Кутафина). 2013. № 9. С. 961-969.

${ }_{13}$ См. подробнее, например: M. Neuner (ed.), National Legislation Incorporating International Crimes. Approaches of Civil and Common Law Countries (BWV 2003).
}

Самый яркий пример в данном отношении, конечно же, даёт нам уголовное законодательство Германии. В 2002 г. там был принят Кодекс международного уголовного права (Völkerstrafgesetzbuch). Как указывает Томас Вайгенд, «немецкое правительство изначально планировало исполнить своё обязательство (по имплементации положений Римского статута. $-\Gamma . E$.) путём простого изменения уголовного кодекса, но в итоге склонилось по практическим, равно как и символическим соображениям, к специальному законодательству... Правительство желало продемонстрировать миру, что Германия рассматривает международные преступления как достаточно серьёзные, так что посвящает специальный закон этому вопросу. Также выяснилось, что даже малое число общих норм, специально требуемых для международных преступлений, повлекло бы необходимость вносить сложные исключения в сжато сформулированные общие нормы уголовного кодекса» ${ }^{14}$. При этом «во многих случаях были найдены жизнеспособные компромиссные решения между полной приверженностью иногда странным или немудрым положениям Статута МУС и сохранением национальных правил и традиций уголовного законодательства» ${ }^{15}$.

Структурно кодекс состоит из Общей и Особенной частей. В Общей части закрепляется принцип универсальной юрисдикции (§ 1), подтверждается действие по общему правилу норм основного УК (§ 2), формулируется особое обстоятельство, исключающее виновность, - приказ или распоряжение (§ 3), устанавливаются правила о командной ответственности (§ 4) и неприменимости сро-

\footnotetext{
${ }^{14} T$. Weigend, 'The Implementation Statute of the ICC in Germany', in K Ligeti (ed) Current Issues of International and European Criminal Law. Lectures in Memory of Imre A. Wiener (Toulouse: Éditions érès, 2010), p. 69.

${ }^{15}$ Ibid., p. 75.
} 
ков давности (§ 5). Особенная часть кодекса устанавливает ответственность за геноцид (§ 6), преступления против человечности (§ 7), военные преступления (§ 8-12) и связанные преступления (§ 13-14).

В Финляндии в 2008 г. глава 11 УК «Военные преступления и преступления против человечности» 1889 г. была серьёзно переработана, и в настоящее время включает нормы, устанавливающие ответственность за геноцид, преступления против человечности, военные преступления, а также, что интересно, за такие деяния, как оборот запрещённых типов вооружения, пытки, анти-этническую агитацию, дискриминацию. В этой же главе формулируются условия ответственности командира, значение приказов правительства и начальника для наступления уголовной ответственности, условия корпоративной уголовной ответственности за анти-этническую агитацию. При этом вначале финское правительство, ратифицировав Римский статут, оставило без изменений нормы УК, сочтя их вполне удовлетворяющими современному состоянию международного уголовного права. Однако критические высказывания (связанные, в частности, с тем, что многие преступления наказывались в рамках санкций лишь «обычного» уголовного права, преступления против человечности как таковые отсутствовали, дефиниция военных преступлений не охватывала вооружённые конфликты немеждународного характера) привели к тому, что в 2005-2008 гг. всеобъемлющая реформа была всё-таки осуществлена ${ }^{16}$.

В Великобритании ст. 50 и сл. Закона о Международном уголовном суде 2001 г. (International Criminal Court Act, 2001, c. 17) предусмотрели ответственность за геноцид,

\footnotetext{
${ }^{16}$ CM.: Jussi Ohisalo, 'Implementation of the Rome Statute in Finland' (2005) 16 Finnish Yearbook of International Law 103-105, 107-120.
}

преступления против человечности (до этого специально не предусматривавшиеся в английском праве и охватывавшиеся нормами «обычного» уголовного права ${ }^{17}$ ) военные преступления путём прямой отсылки к соответствующим положениям Римского статута. Соучастие, подстрекательство, покушение и сокрытие следов этих преступлений наказывается исключительно на основании английского права как деликты sui generis (ст. 52 и 55 закона). В ст. 56 закона специально оговаривается, что общие принципы ответственности за указанные преступления определяются в соответствии с английским правом. Статьи 65 и 66 закона устанавливают общие правила относительно ответственности командиров и психических элементов (mens rea) соответствующих преступлений.

Процессы «одомашнивания» международного уголовного права закономерно привели к росту обвинений в совершении соответствующих преступлений на национальном уровне. По данным, приводившимся Анитой Ушацкой, начиная с 2002 г. в мире имело место более чем 130 случаев преследования в национальных судах за геноцид, преступления против человечности и военные преступления; большинство этих процессов имели место в связи с событиями в Югославии и Руанде, однако собственные национальные дела были инициированы в Аргентине, Ираке, Гватемале, Конго, а также на основе принципа универсальной юрисдикции в ряде европейских государств ${ }^{18}$.

\footnotetext{
${ }^{17}$ CM.: Simon P. Olleson and Matthew R. Brubacher, 'Implementation of the Rome Statute in the United Kingdom' (2005) 16 Finnish Yearbook of International Law 235, 239.

${ }^{18}$ Из выступления Аниты Ушацки 29 мая 2015 г. на Петербургском международном юридическом форуме (круглый стол «Международная и национальная уголовная юстиция. Совместимость и взаимодействие»).
} 
DOI: $10.7256 / 2226-6305.2015 .3 .15751$

При цитировании этой статьи сноска на dоі обязательна

Международное право и международные организации•з•2015 International Law and International Organizations

\section{III. Современные проблемы международно-уголовного права.}

Признание самостоятельности международно-уголовного права не означает, тем не менее, удовлетворённости сегодняшним состоянием дел в этой подотрасли уголовного права. Более того, есть все основания утверждать о кризисе международно-уголовного права в российских реалиях, обусловленном, во-первых, неудовлетворительным состоянием уголовного законодательства в этой сфере и, во-вторых, отсутствием уголовно-политического и научного интереса к этой области уголовного права.

Что касается уголовного законодательства, то его состояние в соответствующей части серьёзно отстало от современного международного и сравнительно-правового опыта. Пожалуй, можно утверждать, что соответствующие положения УК РФ, будучи относительно приемлемы в 1996 г. $^{19}$, сейчас,

\footnotetext{
${ }^{19}$ Хотя действующий УК РФ был принят в 1996 г., формулировки его Особенной части во многом восходят к началу 1990-х гг. Широко распространенное убеждение в 1990-х гг. сводилось к тому, что «нормы УК об ответственности за эти преступления (закреплённых в главе 34 УК РФ. - Г. Е.) основаны на... международно-правовых актах, формулирующих ответственность за преступления против мира, военные преступления и преступления против человечности..., и в значительной степени учитывают их современные модификации, зафиксированные в Уставах Трибуналов для бывшей Югославии и Руанды, Статуте Международного уголовного суда, соответствующих международных конвенциях...» (см.: Лукашук И. И., Наумов А. В. Международное уголовное право: учебник. М., 1999. С. 131-132).

С такой оценкой можно согласиться лишь отчасти. Конечно же, само по себе появление отдельной главы в УК РФ, формулирование отдельных составов преступлений - это значительный шаг вперёд в сравнении с ранее действовавшим законодательством. Вместе с тем говорить про учёт «в значительной степени» международного уголовного права по состоянию на начало и середину 1990-х гг. применительно к УК РФ вряд ли возможно. Достаточно текстуальных сравнений уставов
}

по прошествии почти двух десятилетий, не выдерживают никакой критики как в связи с положениями Общей части, так и соотносительно с отдельными преступлениями в Особенной части УК РФ.

В частности, положения Общей части УК РФ вызывают серьёзные замечания по меньшей мере в части действия уголовного закона в пространстве, института командной ответственности, обстоятельств, исключающих преступность деяния.

Так, принции универсальной юрисдикции (ч. 3 ст. 12 УК РФ) требует для своей реализации наличия международного договора. Возможность осуществления универсальной юрисдикции на основании обычного международного права УК РФ не допускается, и это можно оценить критически. Кроме того, остаётся непрояснённым вопрос о реализации универсальной юрисдикции in absentia, т.e. в отсутствие подозреваемого (обвиняемого) лица на территории Российской Федерации. Часть 3 ст. 12 УК РФ говорит о реализации универсальной юрисдикции в отношении лиц, которые «...не были осуждены в иностранном государстве и привлекаются к уголовной ответственности на территории Российской Федерации». Смысл последней оговорки не вполне ясен, поскольку допускает двоякое толкование: под привлечением к уголовной ответственности здесь можно понимать как

трибуналов по бывшей Югославии и Руанде, Римского статута, чтобы увидеть невыгодное отличие УК РФ в сторону его бо́льшей лаконичности. К тому же отсутствие наказуемости преступлений против человечности, публичных призывов к геноциду (если следовать ст. III(c) Конвенции о предупреждении преступления геноцида и наказании за него 1948 г. в её современном понимании, то «прямое и публичное подстрекательство к совершению геноцида», кроме собственно подстрекательства в смысле ч. 4 ст. 33 УК РФ, включает ещё и публичные призывы в терминологии действующего уголовного закона) - всё это позволяет говорить не о «значительной степени», а напротив, о «незначительной». 
исключительно реальное присутствие подозреваемого (обвиняемого) лица, так и заочное уголовное судопроизводство в отношении лица, не находящегося в России в той мере, в какой таковое допускается российским уголовно-процессуальным законом (ч. 5 ст. 247 УПК РФ) ${ }^{20}$. Оба варианта толкования могут быть обоснованы с равной долей убедительности, и потому необходимо прояснение законодательства.

Ответственность командиров и других начальников, закреплённая п. 2 ст. 86 Дополнительного протокола к Женевским конвенциям от 12 августа 1949 года, касающийся защиты жертв международных вооруженных конфликтов (Протокол I), от 8 июня 1977 г., лишь мозаично имплементирована в национальное право: такую ответственность можно в узких случаях обосновать с помощью нормы о халатности (ст. 293 УК РФ) или в ещё более редких случаях с использованием конструкций соучастия.

Содержащиеся в ст. 37-42 УК РФ нормы об обстоятельствах, исключающих преступность деяния, также могут ставить вопросы. Например, в связи со ст. 42 УК РФ просматривается сразу несколько неясностей. Вопервых, не определён критерий «заведомой незаконности» в ч. 2 ст. 42 УК РФ: предполагает ли закон стандарт «среднего человека» или «данного обвиняемого»? Само по себе понятие «заведомой незаконности» к тому же оставляет больше вопросов, чем даёт отве-

\footnotetext{
${ }^{20}$ Именно на второй вариант, по-видимому, предположительно указывает п. 13 постановления Пленума Верховного Суда РФ от 22 декабря 2009 г. № 28 «О применении судами норм уголовно-процессуального законодательства, регулирующих подготовку уголовного дела к судебному разбирательству», говоря, в частности, о возможности судебного процесса in absentia в случаях особой общественной опасности преступления или в случаях, когда невозможно осуществить экстрадицию обвиняемого.
}

тов $^{21}$. Во-вторых, предположительно необходимо законодательное отнесение к заведомо незаконным приказам или распоряжениям приказов или распоряжений о совершении геноцида и преступлений против человечности (при условии формулирования последнего состава в УК РФ) 22 . В-третьих, непрояснённым остаётся вопрос о квалификации действий лица, отдавшего заведомо незаконные приказ или распоряжение о совершении умышленного преступления (ч. 2 ст. 42 УК РФ); с точки зрения видов соучастников он должен de lege ferenda быть признан организатором преступления.

Вместе с тем наибольшее количество критических замечаний вызывают положения Особенной части УК РФ. Эти замечания могут быть сгруппированы в два блока: отсутствие криминализации деяний, признаваемых преступлениями в международном уголовном праве, и дефектная криминализация.

Что касается первого момента, то наиболее очевидный пробел здесь - это, конечно же, отсутствие криминализации преступлений против человечности. Наказуемость деяний, образующих преступления против человечности, образует норму обычного международного права ${ }^{23}$, однако вследствие конституци-

${ }^{21}$ См. подробнее, например: J. A. Williamson, 'Some Considerations on Command Responsibility and Criminal Liability' (2008) 90 International Review of the Red Cross 303, 316-317.

22 Это предложение было высказано Г. И. Богушем (см.: Богущ Г. И. Общие принципы уголовного права в Римском статуте Международного уголовного суда // Международное уголовное правосудие: современные проблемы / под ред. Г. И. Богуша, Е. Н. Трикоз. М., 2009. С. 92), хотя Е. Н. Субботина полагает такое дополнение излишним, ошибочно полагая, что это и так очевидно (см.: Субботина E. H. Механизм имплементации международного уголовного права в зарубежных странах и в России. М., 2012. С. 95).

${ }^{23}$ Как минимум, обычно-правовой характер установления уголовной ответственности за преступления против человечности можно проследить начиная 
DOI: $10.7256 / 2226-6305.2015 .3 .15751$

При цитировании этой статьи сноска на dоі обязательна

Международное право и международные организации•з•2015 International Law and International Organizations

онного положения (ст. 54 Конституции РФ) и ст. 1, 3 УК РФ привлечение к ответственности предполагает наличие законодательной нормы $^{24}$. Кроме ст. 358 УК РФ (и то очень услов-

с Нюрнбергских принципов 1946 г. (принцип VI); впоследствии это было подтверждено преамбулой и ст. I Конвенции о неприменимости срока давности к военным преступлениям и преступлениям против человечества 1968 г.

Более того, в практике югославского Трибунала запрет совершать военные преступления, преступления против человечности и геноцид рассматривается как норма jus cogens: «...большинство норм международного гуманитарного права, в особенности те, что запрещают военные преступления, преступления против человечности и геноцид, также являются императивными нормами международного права, или jus cogens...» (Prosecutor v Kupreškić et al (Judgement) ICTY-95-16-T, para 520 (14 January 2000).

24 Это самое очевидное толкование норм Конституции РФ и УК РФ. Однако принимая во внимание отсутствие уголовной ответственности за преступления против человечности в УК РФ и возможность совершения таких преступлений, подпадающих под уголовную юрисдикцию Российской Федерации, со временем может возникнуть вопрос либо о прямом привлечении к ответственности на основании норм обычного международного права, либо о наказании соответствующих лиц ex post facto, на основе последующего уголовного закона, криминализирующего преступления против человечности и применимого к более ранним по сравнению с датой его издания событиям.

Первая альтернатива едва ли возможна, так как признавая преступления против человечности в качестве таковых, обычное международное право не предоставляет ни санкции, ни определения состава.

Что касается второй альтернативы, то ситуация выглядит более сложной. Если допустить, что в 2020 г. преступления против человечности будут включены в УК РФ, то можно ли привлечь на основании новой нормы к уголовной ответственности за деяния, совершённые, допустим, в 2015 г.? Прямолинейный ответ на этот вопрос, основывающийся на ч. 1 ст. 54 Конституции РФ и ст. 9-10 УК РФ, слишком «прямолинеен», чтобы быть единственно верным. Первый нюанс связан с тем, что ч. 2 ст. 54 Конституции РФ, предусматривающая, что «никто не может нести ответственность за деяние, которое в момент его совершения не признавалось правонарушением», фактически нивелирует ч. 1 этой же статьи в данном случае, так как новая норма УК РФ не устанавливает ответственность: она лишь её декла- но), говорить о преступлениях против человечности в действующем уголовном законе невозможно. Конечно же, можно утверждать о том, что преступления против человечности фактически охватываются нормами «обычного» уголовного права (о преступлениях против жизни и здоровья (глава 16 УК РФ), против собственности (глава 21 УК РФ) и др.). Вместе с тем, меры наказания в «обычном» уголовном праве не соответствуют тяжести этого деяния; во-вторых, составы преступлений в «обычном» уголовном праве предположительно в

рирует, предусматривая наказание за деяние, которое являлось (должно быть) преступлением в России через действие ч. 4 ст. 15 Конституции РФ.

Второй нюанс - это п. 1 ст. 7 Конвенции о защите прав человека и основных свобод 1950 г., в соответствии с которым «никто не может быть осуждён за совершение какого-либо деяния или за бездействие, которое согласно действовавшему в момент его совершения национальному или международному праву (курсив наш. $-\Gamma$. E.) не являлось уголовным преступлением». Иными словами, это допускает ограниченное существование «деклараторного» уголовного законодательства, применимого ex post facto. Поддержку этой концепции можно усмотреть в Постановлении Европейского Суда по правам человека (Большая палата) от 17 мая 2010 г. (дело «Кононов (Kononov) против Латвии», жалоба № 36376/04). Заявитель в этом деле был фактически осуждён за нарушения в 1944 г. норм обычного международного права, лишь позднее кодифицированных в женевском и гаагском праве и национальном законодательстве Латвии через отсылку к нормам международного гуманитарного права. Европейский Суд поддержал осуждение заявителя, придя к выводу, что «к маю 1944 г. военные преступления были определены как действия, противоречащие законам и обычаям войны, и что международное право выработало основные принципы и предусмотрело обширный набор действий, составляющих такие преступления» (§ 213); нарушения п. 1 ст. 7 Конвенции выявлено не было.

В российской истории схожие случаи имели место в 1940-х гг., когда на основе уже упоминавшегося указа Президиума Верховного Совета СССР от 19 апреля 1943 г. № 39 осуждались лица, совершившие преступные деяния начиная с 22 июня 1941 г. (Краснодарский процесс 1943 г., Харьковский процесс 1943 г. и др. процессы по окончании войны). 
значительной степени пробельны: например, не криминализированы такие разновидности преступлений против человечности, как создание условий жизни, рассчитанных на причинение смерти, обращение в сексуальное рабство, совершение действий, влекущих принудительную беременность, апартеид. Также уже отмечалось отсутствие наказуемости публичных призывов к геноциду (ст. III(c) Конвенции о предупреждении преступления геноцида и наказании за него 1948 г.). Это, пожалуй, наиболее очевидные упущения российского законодателя.

Однако и в связи с имеющимися нормами можно высказать серьёзные замечания, и в особенности они связаны с лаконичными положениями ст. 356 УК РФ. Сравнивая их с многословной ст. 8 Римского статута, можно, казалось бы, восхититься умением нашего законодателя создавать нормы высокого уровня абстракции. Однако это вряд ли возможно. Российскому законодателю в рамках ст. 356 УК РФ удалось сделать то, что не удавалось сделать никому до того и после: «втиснуть»все должные быть уголовно наказуемыми нарушения четырёх Женевских конвенций 1949 г., Дополнительного протокола I 1977 г., других международных договоров и обычного международного права в единый состав преступления. Соответственно, перечень претензий к ст. 356 УК РФ бесконечен: смешение «гаагского» и «женевского» права, упущение из виду обычного международного права, пробелы или, наоборот, сверхохват в криминализации, неразличение международного и немеждународного вооружённого конфликта и т.д. ${ }^{25}$ Иными словами, на определённом

${ }^{25}$ См. подробнее: B. Tuzmukhamedov, 'The Implementation of International Humanitarian Law in the Russian Federation' (2003) International Review of the Red Cross 385, 389391; S. Vasiliev and A. Ogorodova, 'Implementation of этапе создания абстрактной диспозиции её плюсы перечёркиваются одним минусом неопределённостью, когда для применения уголовного закона требуется его раскрытие с привлечением слишком значительного числа нормативных источников, «развёртывание» текста вглубь, не всегда успешное для правоприменителя. В частности, исходя из диспозиции ст. 356 УК РФ, наказуемо «применение в вооруженном конфликте средств и методов, запрещённых международным договором Российской Федерации». Соответственно, для правильной квалификации действий необходимо установить те или иные средства и методы, их запрещённость, соблюдение условий запрещённости в конкретной ситуации и т.п.

Помимо практических сложностей, лаконичная формулировка вызывает также конституционно-правовые сомнения как минимум по двум направлениям.

Во-первых, принцип законности в приложении к уголовному закону означает в том числе определённость уголовного закона, или nullum crimen sine lege certa. В одном из своих решений Конституционный Суд РФ указал, что «принцип формальной определённости закона, предполагающий точность и ясность законодательных предписаний, будучи неотъемлемым элементом верховенства права, выступает как в законотворческой, так и в правоприменительной деятельности в каче-

the Rome Statute in Russia' (2005) 16 Finnish Yearbook of International Law 197, 213-216; Арямов А. А. Преступления против мира и безопасности человечества: хрестоматийный курс лекций. М., 2012. С. 57-58; Трикоз E. Римский статут Международного уголовного суда в Российской Федерации: рамочная модель имплементации // Международное уголовное правосудие: современные проблемы / под ред. Г. И. Богуша, Е. Н. Трикоз. М., 2009. С. 147-148; Лобанов С. А. Современные тенденции кодификации института ответственности за военные преступления // КонсультантПлюс, ๆ 43-51 (Военно-юридический журнал. 2010. № 4). 
стве необходимой гарантии обеспечения эффективной защиты от произвольных преследования, осуждения и наказания. Уголовная ответственность может считаться законно установленной и отвечающей требованиям статьи 55 (часть 3) Конституции Российской Федерации лишь при условии, что она адекватна общественной опасности преступления и что уголовный закон ясно и чётко определяет признаки этого преступления, отграничивая его от иных противоправных и тем более - от законных деяний» ${ }^{26}$.

Однако то, когда законодатель соблюдает эти критерии конституционности, с неизбежностью решается в конституционно-правовой практике ad hoc. В доктрине критерии оценки закона как определённого и, соответственно, конституционного, и наоборот, фактически не разработаны; о желательности исследований в этом направлении лишь указывалось в литературе ${ }^{27}$. Из одного из последних постановлений Конституционного Суда РФ по данному вопросу можно вывести следующее: а) «любое преступление, а равно наказание за его совершение должны быть чётко определены в законе, причём таким образом, чтобы исходя непосредственно из текста соответствующей нормы - в случае необходимости с помощью толкования, данного ей судами, - каждый мог предвидеть уголовно-правовые последствия своих действий (бездействия)»; б) «оценка степени определённости... должна осуществляться исходя не только из самого текста закона, используемых формулировок, но и из их

\footnotetext{
${ }^{26}$ Постановление Конституционного Суда РФ от 27 мая 2008 г. № 8-П по делу о проверке конституционности положения части первой статьи 188 Уголовного кодекса Российской Федерации в связи с жалобой гражданки М. А. Асламазян.

${ }^{27}$ См., например: Жалинский А. Э. Уголовное право в ожидании перемен: теоретико-инструментальный анализ. М., 2008. С. 94, 250-252, 276.
}

места в системе нормативных предписаний, - ...регулятивные нормы, непосредственно закрепляющие те или иные правила поведения, не обязательно должны содержаться в том же нормативном правовом акте, что и нормы, устанавливающие юридическую ответственность за их нарушение» ${ }^{28}$. С учётом адресатов нормы ст. 356 УК РФ, где субъектом преступления могут выступать в том числе обычные граждане, абстрактность диспозиции лишь с очень большой натяжкой позволяет говорить о предвидимости обычным человеком уголовно-правовых последствий своих действий. Исходя из «техничности» норм международного гуманитарного права, когда правомерность или неправомерность действий зависит от нюансов ситуации, отсутствие в законе базового минимума запрещённых действий равноценно превращению предположения о предвидении последствий в фикцию. Иными словами, в таких ситуациях как максимум можно говорить о предвидении уголовно-правовых следствий в смысле наказуемости соответствующих действий по нормам «обычного» уголовного права, но не как военных преступлений; достаточно ли такого предвидения для конституционности ст. 356 УК РФ и привлечения по ней к ответственности - небесспорная теоретическая проблема, связанная с местом осознания противоправности в целом в структуре умысла (ст. 25 УК РФ) ${ }^{29}$.

\footnotetext{
${ }^{28}$ Постановление Конституционного Суда РФ от 17 июня 2014 г. № 18-П по делу о проверке конституционности части четвертой статьи 222 Уголовного кодекса Российской Федерации и статей $1,3,6,8,13$ и 20 Федерального закона «Об оружии» в связи с жалобой гражданки Н. В. Урюпиной.

${ }^{29}$ Виновный может, то есть, осознавать, что совершённые им, например, хищение чужого имущества во время вооружённого конфликта, умышленные уничтожение или повреждение такого имущества, причинение вреда здоровью, истязание, изнасилование, т.п. образуют «обычное» уголовное преступление, но не военное
} 
Во-вторых, конституционно-правовое значение приобретают соображения надлежащей дифференциации уголовной ответственности. Санкция ст. 356 УК РФ предусматривает наказание от двух месяцев до двадцати лет лишения свободы. В части такой свободы судейского усмотрения при назначении основного вида наказания это единственная норма в УК РФ. Соответственно, даже оставляя в стороне вопросы квалификации по совокупности преступлений, хищение чужого имущества во время вооружённого конфликта, умышленные уничтожение или повреждение такого имущества (охватывающиеся одной из альтернатив в действующей редакции ст. 356 УК РФ) могут быть наказаны столь же строго, как и, например, истязание, изнасилование, насильственные действия сексуального характера, биологические или иные эксперименты (также охватывающиеся одной из альтернатив в действующей редакции ст. 356 УК РФ), хотя очевидно не совпадают с указанными действиями по характеру общественной опасности, и в любом случае намного строже, чем соответствующие «обычные» преступления. Между тем, надлежащая дифференциация уголовной ответственности в зависимости от общественной опасности деяния и порождённых им последствий есть отражение конституционных принципов равенства и справедливости ${ }^{30}$. При этом ссылку на судейское усмотрение при назначении наказания как гарантию надлежащей дифференциации ответственности вряд ли можно признать приемлемой.

преступление. Достаточно ли только такого осознания для констатации умысла?

${ }^{30}$ Постановление Конституционного Суда РФ от 11 декабря 2014 г. № 32-П по делу о проверке конституционности положений статьи $159^{4}$ Уголовного кодекса Российской Федерации в связи с запросом Салехардского городского суда Ямало-Ненецкого автономного округа.
Таким образом, помимо собственно материально-правовых замечаний к своему содержанию, некоторые нормы главы 34 УК РФ могут быть ещё и поставлены под сомнение с точки зрения Конституции РФ.

Следуя далее, отсутствие уголовно-политического и научного интереса к международно-уголовному праву - достаточно деликатный вопрос, связанный с констатацией пренебрежения в уголовно-правовой доктрине вопросами как международного уголовного права в целом, так и в частности применительно к национальному уровню. Понимая, что сказанное далее может быть обидно для тех, кто занимается этой проблематикой, однако очевиден факт того, что в мировом глобализированном научном сообществе на этом поле «играют» лишь единицы представителей России ${ }^{31}$, и не они «задают тон» в современном развитии международ-

31 Самое очевидное подтверждение тому - стремящееся к нулю количество статей российских авторов на lingua franca современного международного уголовного права и такое же количество ссылок на их работы (пусть даже на русском языке) в ведущих публикациях на эту тему. И обратная ситуация, когда множество выходящих в России работ по международному уголовному праву пестрят отсылками к работам советской эпохи и либо вообще не содержат ссылок на современную зарубежную литературу, либо содержат их в мизерном количестве. Едва ли не самое опасное в последнем случае - это склонность авторов, слабо знакомых с современными основополагающими публикациями, практикой международных судебных учреждений, «русифицировать» международное уголовное право за счёт привнесения в него уголовно-правовых конструкций, свойственных национальному праву, таких как состав преступления, соучастие, множественность и т.п. Такой подход, всецело приемлемый на уровне национального права, если не искажает действительное содержание международного уголовного права, то по меньшей мере создаёт ложное впечатление о нём.

Достаточно взвешенную оценку современной российской доктрины в этой части см.: Lauri Mälksoo, Russian Approaches to International Law (OUP 2015) 136-139. 
ного уголовного права ${ }^{32}$. Мы национально замкнуты, отделены от мировой науки, и преодоление этой пропасти - вопрос первостепенной важности.

В заключение отметим, что в сложившейся ситуации есть как минимум два варианта развития событий. Первый заключается в повторении заклинания «у нас всё хорошо» со ссылкой на кодекс в редакции 1996 г., хотя за окном 2015 г. Второй вариант сложнее, ибо требует и законодательных шагов по преодолению очевидных упущений и отсталостей, и научной активности. Но именно он желателен для того, чтобы по прошествии времени мы не могли гордиться в этой области только именами и событиями давно минувших дней.

\section{Библиография:}

1. B. Tuzmukhamedov, 'The Implementation of International Humanitarian Law in the Russian Federation' (2003) International Review of the Red Cross 385.

2. Francine Hirsch, 'The Soviets at Nuremberg: International Law, Propaganda, and the Making of the Postwar Order' (2008) 113 American Historical Review 701.

3. Helmut Satzger, International and European Criminal Law (CH Beck 2012).

4. J. A. Williamson, 'Some Considerations on Command Responsibility and Criminal Liability' (2008) 90 International Review of the Red Cross 303.

5. Jussi Ohisalo, 'Implementation of the Rome Statute in Finland' (2005) 16 Finnish Yearbook of International Law 103.

6. Kirsten Sellars, 'Crimes against Peace' and International Law (CUP 2013).

7. Lauri Mälksoo, Russian Approaches to International Law (OUP 2015).

8. M. Neuner (ed.), National Legislation Incorporating International Crimes. Approaches of Civil and Common Law Countries (BWV 2003).

9. Matthias Goldmann, 'Implementing the Rome Statute in Europe: From Sovereign Distinction to Convergence in International Criminal Law?' (2005) 16 Finnish Yearbook of International Law 5.

10. S. Vasiliev and A. Ogorodova, 'Implementation of the Rome Statute in Russia' (2005) 16 Finnish Yearbook of International Law 197.

11. Simon P. Olleson and Matthew R. Brubacher, 'Implementation of the Rome Statute in the United Kingdom' (2005) 16 Finnish Yearbook of International Law 235.

12. T. Weigend, 'The Implementation Statute of the ICC in Germany', in K Ligeti (ed) Current Issues of International and European Criminal Law. Lectures in Memory of Imre A. Wiener (Toulouse: Éditions érès, 2010).

\footnotetext{
${ }^{32}$ В такой ситуации парадоксально читать, что «советской правовой доктрине принадлежит особая роль в деле отраслевого обособления международного уголовного права. Общепризнано, что советская наука отличалась глубокой и, по сути, лучшей в мире теоретической разработкой концепции “международного преступления”» (см.: Елисеев Р. А. Зарождение и развитие науки международного уголовного права // КонсультантПлюс, \ 97 (Международное публичное и частное право. 2009. № 6). Кроме того, что непонятно, кем это «общепризнано», так и в целом оценка представляется чрезмерно хвалебной. По сути же, после А. Н. Трайнина, действительно высоко ценимого в западной литературе (но опять-таки, наряду с
}

Хершем Лаутерпахтом, годом раньше предложившим криминализацию агрессии, и другими европейскими авторами) за его вклад в развитие международного уголовного права в Нюрнбергскую эпоху (в особенности за понятия «преступления против мира» и «общий план или сговор») (см., например: Kirsten Sellars, 'Crimes against Peace' and International Law (CUP 2013) 48-52, 55-58, 109-110; Francine Hirsch, 'The Soviets at Nuremberg: International Law, Propaganda, and the Making of the Postwar Order' (2008) 113 American Historical Review 701730), все остальные имена, цитируемые упомянутым автором, известны только в России и в лучшем случае имеют только несколько упоминаний в мировой литературе. 
13. Арямов А. А. Преступления против мира и безопасности человечества: хрестоматийный курс лекций. M., 2012.

14. Богуш Г. И. Общие принципы уголовного права в Римском статуте Международного уголовного суда // Международное уголовное правосудие: современные проблемы / под ред. Г. И. Богуша, Е. Н. Трикоз. M., 2009.

15. Верле Г. Принципы международного уголовного права / пер. с англ. С. В. Саяпина. Одесса; М., 2011.

16. Воинский устав о наказаниях. 6-е изд. / сост. В. Ф. Огнев, испр. и доп. А. С. Лыкошин. Пг., 1916.

17. Елисеев Р. А. Зарождение и развитие науки международного уголовного права // Международное публичное и частное право. 2009. № 6.

18. Есаков Г. А. Экономическое уголовное право: понятие, содержание и перспективы // Lex Russica (Hayчные труды Московского государственного юридического университета имени О. Е. Кутафина). 2013. № 9.

19. Жалинский А. Э. Уголовное право в ожидании перемен: теоретико-инструментальный анализ. М., 2008.

20. Лобанов С. А. Современные тенденции кодификации института ответственности за военные преступления // Военно-юридический журнал. 2010. № 4.

21. Лукашук И. И., Наумов А. В. Международное уголовное право: учебник. М., 1999.

22. Субботина Е. Н. Механизм имплементации международного уголовного права в зарубежных странах и в России. М., 2012.

23. Трикоз Е. Римский статут Международного уголовного суда в Российской Федерации: рамочная модель имплементации Международное уголовное правосудие: современные проблемы / под ред. Г. И. Богуша, Е. Н. Трикоз. М., 2009.

24. Трунцевский Ю. В., Цветков А. А. Способы инкорпорации международно-правовых норм в российской уголовно-правовой системе // Международное публичное и частное право. 2005. № 2.

\section{References (transliterated):}

1. B. Tuzmukhamedov, 'The Implementation of International Humanitarian Law in the Russian Federation' (2003) International Review of the Red Cross 385.

2. Francine Hirsch, 'The Soviets at Nuremberg: International Law, Propaganda, and the Making of the Postwar Order' (2008) 113 American Historical Review 701.

3. Helmut Satzger, International and European Criminal Law (CH Beck 2012).

4. J. A. Williamson, 'Some Considerations on Command Responsibility and Criminal Liability' (2008) 90 International Review of the Red Cross 303.

5. Jussi Ohisalo, 'Implementation of the Rome Statute in Finland' (2005) 16 Finnish Yearbook of International Law 103.

6. Kirsten Sellars, 'Crimes against Peace’ and International Law (CUP 2013).

7. Lauri Mälksoo, Russian Approaches to International Law (OUP 2015).

8. M. Neuner (ed.), National Legislation Incorporating International Crimes. Approaches of Civil and Common Law Countries (BWV 2003).

9. Matthias Goldmann, 'Implementing the Rome Statute in Europe: From Sovereign Distinction to Convergence in International Criminal Law?' (2005) 16 Finnish Yearbook of International Law 5.

10. S. Vasiliev and A. Ogorodova, 'Implementation of the Rome Statute in Russia' (2005) 16 Finnish Yearbook of International Law 197.

11. Simon P. Olleson and Matthew R. Brubacher, 'Implementation of the Rome Statute in the United Kingdom' (2005) 16 Finnish Yearbook of International Law 235.

12. T. Weigend, 'The Implementation Statute of the ICC in Germany', in K Ligeti (ed) Current Issues of International and European Criminal Law. Lectures in Memory of Imre A. Wiener (Toulouse: Éditions érès, 2010).

13. Aryamov A. A. Prestupleniya protiv mira i bezopasnosti chelovechestva: khrestomatiinyi kurs lektsii. M., 2012. 
DOI: $10.7256 / 2226-6305.2015 .3 .15751$

При цитировании этой статьи сноска на dоі обязательна

Международное право и международные организации•3•2015

International Law and International Organizations

14. Bogush G. I. Obshchie printsipy ugolovnogo prava v Rimskom statute Mezhdunarodnogo ugolovnogo suda // Mezhdunarodnoe ugolovnoe pravosudie: sovremennye problemy / pod red. G. I. Bogusha, E. N. Trikoz. M., 2009.

15. Verle G. Printsipy mezhdunarodnogo ugolovnogo prava / per. s angl. S. V. Sayapina. Odessa; M., 2011.

16. Eliseev R. A. Zarozhdenie i razvitie nauki mezhdunarodnogo ugolovnogo prava // Mezhdunarodnoe publichnoe i chastnoe pravo. 2009. № 6 .

17. Esakov G. A. Ekonomicheskoe ugolovnoe pravo: ponyatie, soderzhanie i perspektivy // Lex Russica (Nauchnye trudy Moskovskogo gosudarstvennogo yuridicheskogo universiteta imeni O. E. Kutafina). 2013. № 9.

18. Zhalinskii A. E. Ugolovnoe pravo v ozhidanii peremen: teoretiko-instrumental'nyi analiz. M., 2008.

19. Lobanov S. A. Sovremennye tendentsii kodifikatsii instituta otvetstvennosti za voennye prestupleniya // Voennoyuridicheskii zhurnal. 2010. № 4.

20. Lukashuk I. I., Naumov A. V. Mezhdunarodnoe ugolovnoe pravo: uchebnik. M., 1999.

21. Subbotina E. N. Mekhanizm implementatsii mezhdunarodnogo ugolovnogo prava $\mathrm{v}$ zarubezhnykh stranakh $\mathrm{i}$ v Rossii. M., 2012.

22. Trikoz E. Rimskii statut Mezhdunarodnogo ugolovnogo suda v Rossiiskoi Federatsii: ramochnaya model' implementatsii Mezhdunarodnoe ugolovnoe pravosudie: sovremennye problemy / pod red. G. I. Bogusha, E. N. Trikoz. M., 2009.

23. Truntsevskii Yu. V., Tsvetkov A. A. Sposoby inkorporatsii mezhdunarodno-pravovykh norm v rossiiskoi ugolovno-pravovoi sisteme // Mezhdunarodnoe publichnoe i chastnoe pravo. 2005. № 2. 